\section{Resilience measurement of longwall machinery}

Rudarsko-geološko-naftni zbornik

(The Mining-Geology-Petroleum Engineering Bulletin) UDC: 625:007

DOI: 10.17794/rgn.2020.3.4

Original scientific paper

\author{
Sasan Heydari'; Seyed Hadi Hoseinie ${ }^{{ }^{*}}$; Behzad Ghodrati²; Uday Kumar ${ }^{2}$ \\ ${ }^{1}$ Mining Machinery Laboratory, Department of Mining Engineering, Isfahan University of Technology, 8415683111 Isfahan, Iran \\ ${ }^{2}$ Division of Operation and Maintenance Engineering, Lulea University of Technology, Lulea, Sweden
}

\begin{abstract}
This paper attempts to apply the resilience concept to the mining sector, especially to mining machinery and production systems. The quantitative analysis method using the linear recovery function has been applied. As the core part of the proposed method, it is assumed that in the mining machinery fleet, the performance function falls to a "zero" value immediately after the occurrence of a failure. Therefore, the resilience calculation process runs through the concept of time to repair and machine maintainability. As a case study for the proposed concept, the operation and failure data of the drum shearer machine in Parvadeh longwall mine in Iran is applied. The data pertains to a coal cutting operation in a whole longwall panel over the period of two years. In total, the calculations encompass over 2600 hours of actual operation and 171.8 hours of repair time, which reveals that the studied shearer has a resilience of 96.7 percent. Along with the case study results, it is confirmed by this paper that resilience as a developing concept could be adequately applied to coal mining systems as a support measure for production assurance and reliability.
\end{abstract}

\title{
Keywords:
}

coal; drum shearer; time to repair; performance function.

\section{Introduction}

Longwall mining systems are generally characterized by high productivity, low operation costs, and continuity of operations. Maintaining the continuity of operations is vital for any longwall system, keeping in mind the restrictions of the longwall method. One of the most critical factors in achieving smooth production is integrating various machines (plow/shearer, AFC, and roof supports) and controlling their interactions within the face production chain to keep the operation in "up" or "running" mode (Mundry et al., 2015). Since the reliability network of the production chain is in series form in longwall faces, the stoppage of any machinery directly forces the cutting operation and whole production to stop. Therefore, the recovery rate of failed machinery significantly affects the face productivity and production rate. One of the most applicable indexes to measure the recovery rate of engineering systems is "resilience," which is defined based on the recovery potential of the systems from the "down" to the "up" mode.

Recently, intensive attention has been paid to the analysis of multifactorial solutions in the design of any mining process as a prerequisite for maintaining stable technical and economic production conditions in coal

Corresponding author: Seyed Hadi Hoseinie

hadi.hoseinie@iut.ac.ir mines (Lozynskyi et al., 2020). In the case of facing disruptive events, the operation structure had to deal with urgent and short-term logistic issues in applying methods which are generally focused on high reliability and on the ability of diverse systems to maintain or recover their functionalities in a challenging environment (Urruty et al., 2016). During the past three decades, all manufacturers and mining companies tried to enhance the reliability of mining fleets. Nevertheless, finally, they realized that achieving high-reliability levels in harsh environments such as mining operations is considerably costly, and it does not assure the operational availability directly. Therefore, as a new non-costly approach, the resilience and recovery rate of the machinery is focused on getting the maximum output from the mining fleets.

A precise analytical framework associated with disaster in the mining system is still lacking, and hence limits their usefulness to assess the ability of mining systems to cope with perturbations. Due to the often expensive nature of resilience, maintaining or improving performance is frequently given priority. In particular, there is a pressing need to develop methods to manage resilience in mining systems (Uday and Marais, 2015).

In mining industries, resilience analysis hasn't been studied systematically and fundamentally; however, a wide range of reliability studies have been conducted. Therefore, in this study, the resilience of cutting opera- 
tions in longwall mines is studied using a more focused quantitative approach. For this purpose, failure data for the drum shearer machine in Parvadeh coal mine has been collected and applied.

In the following sections of this paper, after presenting the mathematical definition of resilience, the collected data from the case study mine is analyzed. Finally, the resilience measurement of the drum shearer machine is calculated.

\section{Resilience of engineering systems}

Based on extensive available literature from various scientific backgrounds, resilience has been characterized and defined in a wide range of concepts and different points of view. However, some of those are more general and have been accepted by researchers significantly. As one of the basic and general definitions, Kendra and Wachtendorf (2003) defined resilience as "the system's ability to sustain a shock without completely deteriorating; that is, most conceptions of resilience involve some idea of adapting to and bouncing back from disruption." The concept of resilience is commonly used to denote both the strength and the flexibility of systems (Bruneau et al., 2003). So far, the implementation of the resilience concept has been widely marked in various engineering disciplines. Resilience is particularly appropriate when the system is expected to survive and recover from low-frequency high-impact disruptions (Uday and Marais, 2015). Most engineering systems are associated with different levels of uncertainty and potentially harsh operating environments, which result in the fluctuation of system performance over time $(\mathrm{P}(t))$ (Yodo and Wang, 2016). Figure 1 presents the performance of a resilient system in comparison with a nonresilient one after being subjected to a failure event.

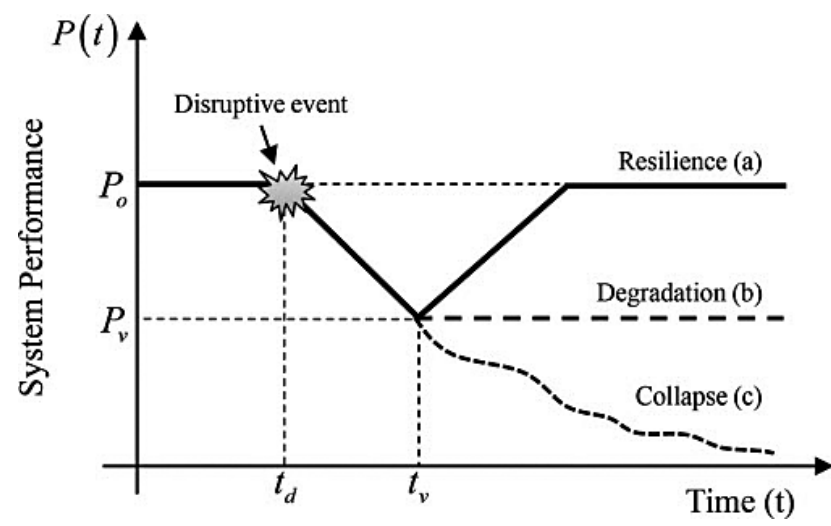

Figure 1: Resilient versus non-resilient behavior of systems (from Yodo and Wang, 2016)

The resilience concept arises when the system is expected to survive and must be rapidly recovered from disturbances. However, in such conditions, the reliability concept faces philosophical challenges. In most of the past studies, the qualitative measure of resilience has been explored and discussed based on the resilience curve (Ayyub, 2015; Rose, 2007; Uday and Marais, 2014; Ouyang et al., 2012; Henry and Ramirez-Marquez, 2012; Han et al., 2012; Zobel and Khansa, 2014; Dessavre et al., 2016; Shafieezadeh and Burden, 2014; Omer et al., 2013; Alipour and Shafei, 2016; Miller-Hooks et al., 2012; Cox et al., 2011; Wang and Ip, 2009; Munoz and Dunbar, 2015; Dixit et al., 2016; Li and Lence, 2007). Another group of researchers has attempted to quantify the resilience metrics based on the geometrical characteristics of the resilience curve. For example, according to Figure 2, Bruneau et al. (2003) concluded that the loss of resilience is the shaded area. If the area is enclosed by a nonlinear recovery profile, the performance loss can be approximated using the integral method. Ayyub (2015) and Rose (2007) named the shaded area of concern in Figure 2 as the resilience triangle, and Zobel (2014) found that when the recovery profile in Figure $\mathbf{2}$ is assumed to be linear, a triangle formulation can be integrated to quantify the resilience. Renschler (2010) reported that system performance does not necessarily show a steep or extreme drop in the aftermath of a disruptive event. Most of the regular performance drops exhibit nonlinear behaviour. Mathematically, it can be quantified as the normalized shaded region under the system response (describing the functionality of a system) using the integral method.

Resilience could be applied to multiple different scales and units of analysis, ranging from an individual to a global scale. The resilience of a system depends on its serviceability performance. In this conceptual approach, the performance of a system can range between 0 to $100 \%$, where $100 \%$ indicates that the system is in a satisfactory state and $0 \%$ means no service is available, the system is in an unsatisfactory state or it has failed. Failures usually decrease the serviceability of a system. The restoration of the system starts after the failure, and it finishes when the serviceability reaches its initial state. The loss of resilience is thought to be equal to the service degradation of the system over the whole restoration period. According to Figure 2, resilience could be mathematically defined as Equation (1) (Kammouh et al., 2019). This equation can be applied to measure the loss of resilience for a single failure in a system. An advantage of this proposed measure is its simplicity. How-

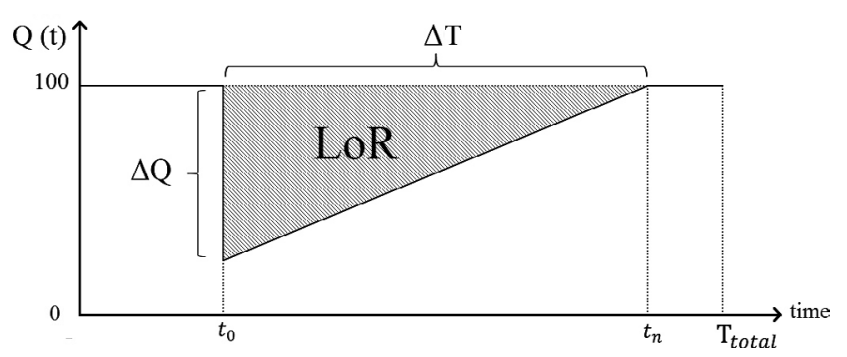

Figure 2: Conceptual representation of resilience for a single failure in the time zone of $T_{\text {total }}$ 
ever, its linear recovery mode may not be realistic for some systems and events. Furthermore, the degradation of performance after a disruptive event is immediate, which may be realistic for some systems such as mining machinery. Nevertheless, some systems may see a more gradual decrease over time.

$$
L O R=\int_{t_{0}}^{t_{n}}[100-Q(t)] d t=\frac{(\Delta T \times \Delta Q)}{2}
$$

Where:

$L O R$ - the measure of loss of resilience (\%),

$Q(t)$ - performance function or the quality of the system at time $t$,

$t_{0} \quad-$ the time at which the failure occurs,

$t_{n} \quad$ - the time at which the system returns to its satisfactory state,

$\Delta T$ - equal to the time to repair of a single failure,

$\Delta Q$ - reduced amount of system performance due to a failure.

Larger LOR values indicate lower resilience and vice versa. According to Cimellaro et al. (2010), the LOR has to be normalized to be time-independent by dividing over $T_{\text {total }}$, which is the total analysis time of the system. Thus, Equation (1) can be replaced by Equation (2):

$$
L O R=\int_{t_{0}}^{t_{n}} \frac{[100-Q(t)]}{T_{\text {total }}} d t
$$

In the long-running time, machinery faces many failure events. Thus, the LOR is calculated by the summation of the LORs of all failures. Equation (2) could be expanded to measure the loss of resilience due to the set of the recovery process. Therefore, the summation of all proposed recovery processes is technically equal to the overall loss of resilience of the system. This concept is shown in Figure 3 and is calculated by using Equation (3) and (4).

$$
\begin{gathered}
L_{\text {Overal }}=\sum_{i=1}^{I} L O R_{i} \\
L O R_{\text {overal }}=\sum_{i=1}^{I} \frac{\frac{\left(\Delta T_{i} \times \Delta Q_{i}\right)}{2}}{T_{\text {total }}}=\frac{1}{2 T_{\text {total }} \sum_{i=1}^{I} \Delta T_{i} \times \Delta Q_{i}}
\end{gathered}
$$

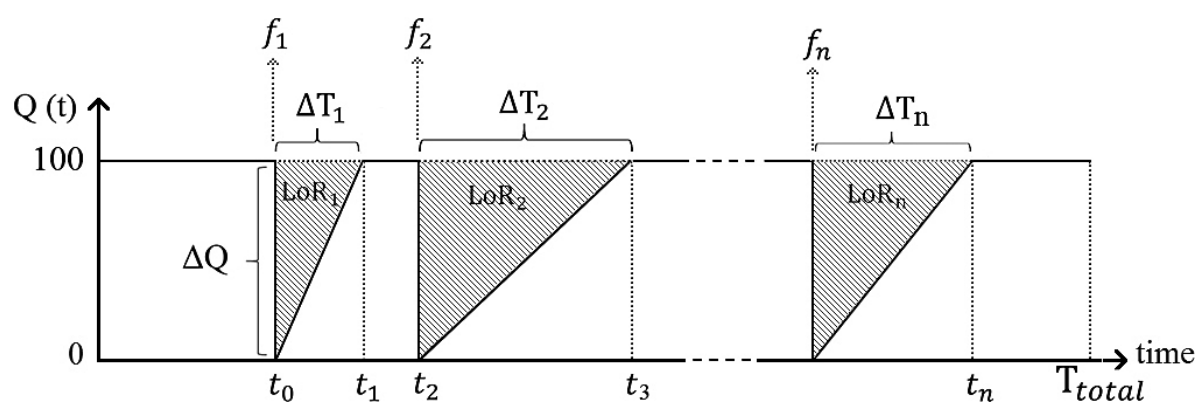

Figure 3: LoR in series of disruptive failures and related LoRs
Where:

$L O R_{\text {overal }}$ - the overall loss of resilience of the whole system,

$L O R_{i} \quad-$ loss of resilience due to $i$ th failure.

In a fleet of mining machinery, most of the failures lead the operation to a complete or rapid shutdown and production stoppage (even in advanced mining machinery, the machine stops automatically by some machine health control systems or based on mine safety platforms and regulations). Immediately after failure occurrences, the system performance falls to zero. Therefore, in the adoption of Equation (3) to mining machinery, $\Delta Q$ of all failure events is equal to 100 and Equation (4) could be replaced by Equation (5):

$$
L_{O R_{\text {overal }}}=\frac{50}{T_{\text {total }}}=\sum_{i=1}^{I} \Delta T_{i}
$$

In the following sections of this paper, the proposed concept is applied to measure the resilience of the drum shearer machine operating in Parvadeh longwall mine, Iran.

\section{Case study on longwall shearer machine}

As mentioned in the mathematical concept of the study, the main requirement of resilience analysis is the time to repair (TTR) data from any engineering system. In this paper, for failure and time to repair analysis, a set of maintenance data from the drum shearer machine in Parvadeh longwall mine has been collected and applied. The available data pertains to a coal cutting operation in a whole panel of the mine, which was collected over the period of two years. The data consists of 129 failures and the related time for repairs. The failure event map of all studied failures is presented in Figure 4.

\subsection{Statistical data analysis and maintainability studies}

To find the best probability density function of repair times, different types of statistical distributions including Lognormal, Gamma, Generalized Gamma, Weibull (two and three parameters), Normal, Logistic, and Log- 
Table 1. The result of time to repair data analysis of studied shearer

\begin{tabular}{|c|c|c|}
\hline Distribution & $\begin{array}{l}\text { Anderson-Darling } \\
\text { goodness-of-fit test }\end{array}$ & The best-fitted distribution function \\
\hline Lognormal (3 parameters) & 0.63 & \multirow{6}{*}{$\begin{array}{l}\text { Lognormal (3 parameters): } \\
\mathrm{f}(\mathrm{t})=0.038\left(\frac{t}{43.48}\right)^{0.665}\left(1+\left(\frac{t}{43.48}\right)^{1.665}\right)^{-2}\end{array}$} \\
\hline LogLogistic (3 parameters) & 0.70 & \\
\hline Lognormal & 1.47 & \\
\hline LogLogistic & 1.61 & \\
\hline Weibull (3 parameters) & 1.68 & \\
\hline Gamma & 3.21 & \\
\hline
\end{tabular}

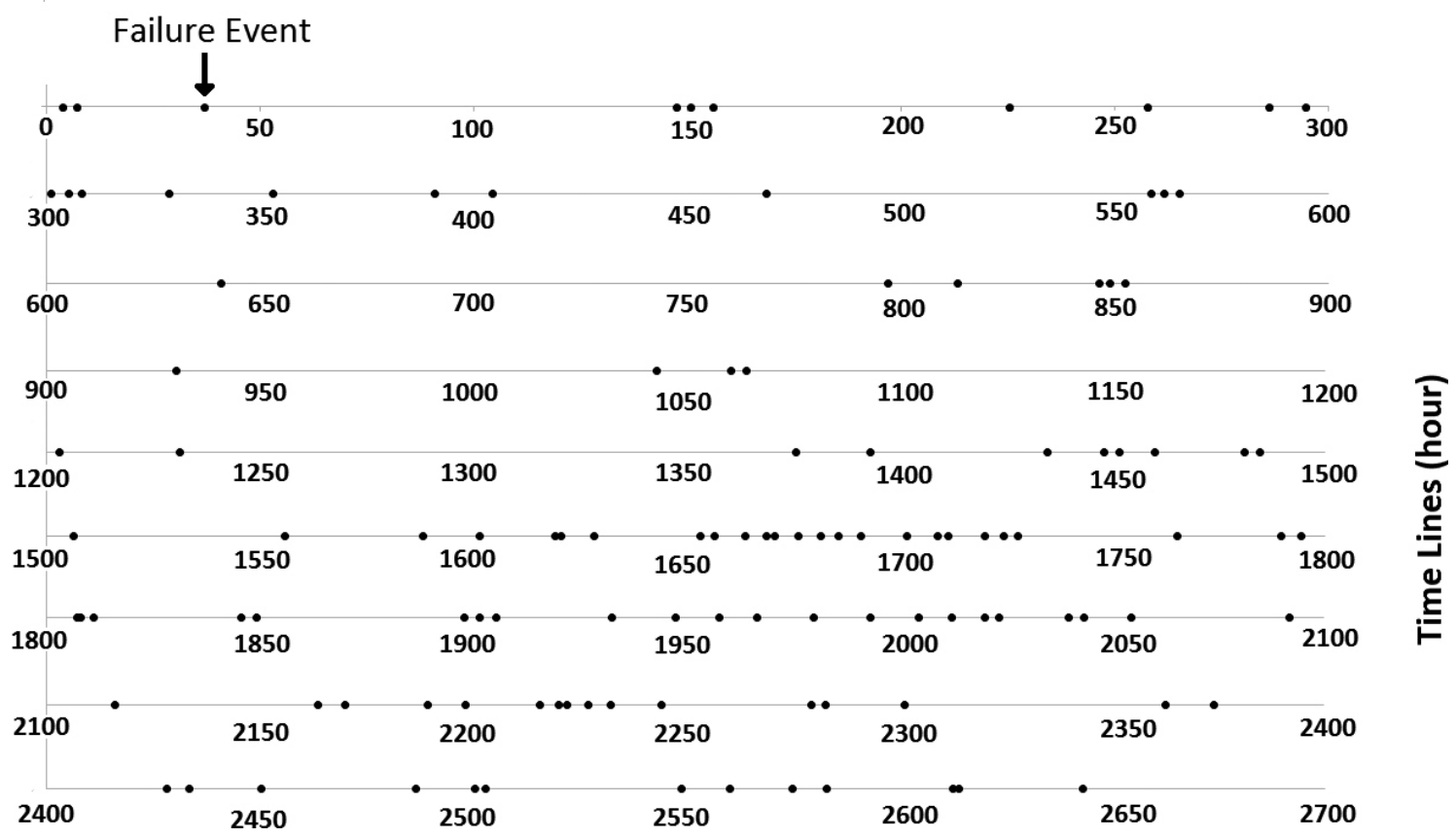

Figure 4: Failure event map of studied drum shearer
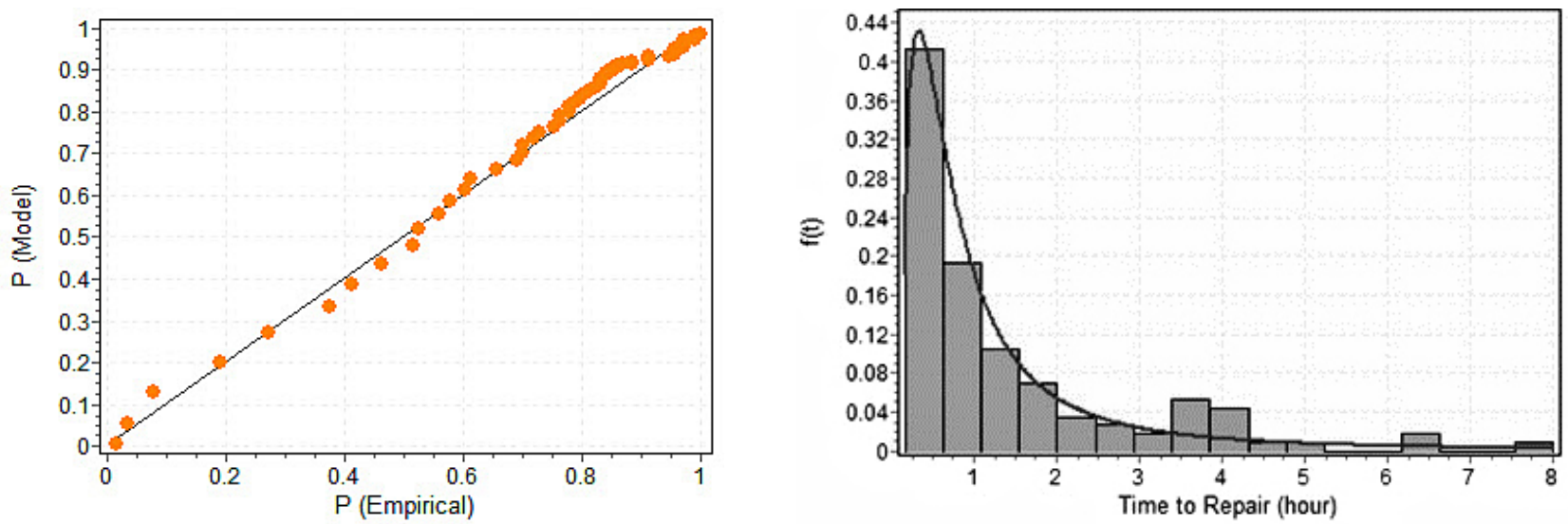

Figure 5: Histogram of times to repair data and best-fitted distribution (right), PP plot of empirical data and fitted distribution outputs (left)

Logistic, were tested on the available data using Easyfit software. Since the amount of data is acceptably high (129 points of data), the Anderson-Darling goodness-offit test was used for selecting the best distribution among the choices. The results of data analyses are illustrated in Table 1 and Figure 5. The calculations show that the time to repair the studied machine varies from 0.17 to 8 hours with 1.34 hours as the mean time to repair (MTTR). 
This means that the failures of the drum shearer machine of the Parvadeh Mine don't usually last very long. The analysis shows that the studied shearer is recovered from "down" mode to "up" or operational mode in less than 2.2 hours, with a probability of 80 percent. This value is an essential measure in production and maintenance management.

In total, all mentioned 129 failures of the shearer had taken 171.8 hours of repair time, which generally represents the recovery time of systems. During the studied time of operation, the shearer was in operation for almost 2600 hours of coal cutting. Therefore, the total studied period for resilience analysis of this machine is equal to 2771 hours. By these values and considering the mentioned assumption (the $\Delta Q=100$ ) and applying Equation (5), the overall LOR is $3.1 \%$. Therefore, the overall resilience of the studied shearer machine during the mentioned period is $96.9 \%$.

\section{Conclusion}

Engineering resilience is a measure that describes the ability of an engineered system to maintain its functionality by resisting and recovering against adverse events. Unfortunately, this useful concept has not been implemented in the mining industry significantly.

This paper has proposed and demonstrated a simple quantitative framework for measuring resilience for mining machinery by focusing on a longwall drum shearer as a case study. The study is built on the assumption that machine performance reduces to zero immediately after failure events, which we call binary behaviour. The analysis of 129 failure events and the related repair and recovery process in Parvadeh coal mine reveals that the mean time to repair is 1.34 hours. The associated loss of resilience during the 2771 hours of coal cutting operations by the case study drum shearer is equal to 3.1 percent. In total, 171 hours of repair time were linearly spent to recover the shearer machine to operate with 100 percent performance in the extraction of a whole longwall panel.

Along with case study results, this paper reveals that the resilience concept as a developing philosophy of production systems could efficiently support decisionmaking in advanced mining systems to reach a high level of production assurance and reliability. This paper addresses the resilience of mining machinery in a simple structure and concept without any stochastic changes in the failure behaviour. For further studies, the time-dependent behaviour of the machine, along with its failure behaviour fluctuation, especially the recovery function type, should be considered and modelled in detail.

\section{Acknowledgment}

The current research has been carried out in close collaboration with Parvadeh Coal Mine Co. for data collec- tion and validation of results. Therefore, the kind support of this company's employees and managers is warmly acknowledged.

\section{References}

Alipour, A., Shafei, B. (2016): Seismic Resilience of Transportation Networks with Deteriorating Components. Journal of Structural Engineering, 142, 8, C4015015-1 C4015015-15.

Arsenault, D. (2007): Critical Thinking: Moving from Infrastructure Protection to Infrastructure Resilience. CIP Program Discussion Paper Series, 1-9.

Ayyub, B.M. (2015): Systems Resilience for Multi-hazard Environments: Definition, Metrics, and Valuation for Decision Making. Risk Analysis, 34, 340-355.

Bruneau, M., et al. (2003): A Framework to Quantitatively Assess and Enhance the Seismic Resilience of Communities. Earthquake Spectra, 19, 733-752.

Cimellaro, G.P., Reinhorn, A.M., Bruneau, M. (2010): Framework for analytical quantification of disaster, resilience. Engineering Structures, 32, 3639-3649.

Cox, A., Prager, F., Rose, A. (2011): Transportation Security and the Role of Resilience: A Foundation for Operational Metrics. Transport Policy, 18, 2, 307-317.

Dessavre, D.G., Ramirez-Marquez, J. E., Barker, K. (2016): Multidimensional Approach to Complex System Resilience Analysis. Reliability Engineering \& System Safety, 149, 34-43.

Dixit, V., Seshadrinath, N., Tiwari, M. K. (2016): Performance Measures Based Optimization of Supply Chain Network Resilience: A NSGA-IIp Co- Kriging Approach. Computers \& Industrial Engineering, 93, 205-214.

Han, S.Y., Marais, K., DeLaurentis, D. (2012): Evaluating System of Systems Resilience Using Interdependency Analysis. Proceeding of IEEE International Conference on Systems, Man, and Cybernetics (SMC), Seoul, Korea, 1251-1256.

Henry, D., Ramirez-Marquez, J. E. (2012): Generic Metrics and Quantitative Approaches for System Resilience as a Function of Time. Reliability Engineering \& System Safety, 99, 114-122.

Kammouh, O., Zamani-Noori, A., Cimellaro, G.P., Mahin, S.A. (2019): Resilience Evaluation of Urban Communities. ASCE-ASME Journal of Risk and Uncertainty in Engineering Systems, Part A: Civil Engineering, 5, 1, 1-17.

Kendra, J.M., Wachtendorf, T. (2003): Elements of Resilience after the World Trade Center Disaster: Reconstituting New York City's Emergency Operations Centre. Disasters, 27, $37-53$.

Li, Y., Lence, B. J. (2007): Estimating Resilience for Water Resources Systems. Water Resource Research, 43, 7, 1-11.

Lozynskyi, V., Medianyk, V., Saik, P., Rysbekov, K., Demydov, M. (2020): Multivariance solutions for designing new levels of coal mines, The Mining-Geology-Petroleum Engineering Bulletin, 35, 2, 73-83. 
Miller-Hooks, E., Zhang, X., Faturechi, R. (2012): Measuring and Maximizing Resilience of Freight Transportation Networks. Computers \& Operations Research, 39, 7, 1633-1643.

Mundry, S., Gajetzki, M., Hoseinie, S.H. (2015): Longwall automation - productivity and coal quality enhancement. International Journal of Mining, Reclamation and Environment, 29, 357-367.

Munoz, A., Dunbar, M. (2015): On the Quantification of Operational Supply Chain Resilience. International journal production research, 53, 22, 6736-6751.

Omer, M., Mostashari, A., Nilchiani, R. (2013): Assessing Resilience in a Regional Road-Based Transportation Network. International journal industrial and systems engineering, 13, 389-408.

Ouyang, M., Duenas-Osorio, L., Min, X. (2012): A ThreeStage Resilience Analysis Framework for Urban Infrastructure Systems. Structural Safety, 36, 23-31.

Rose, A. (2007): Economic resilience to natural and manmade disasters: Multidisciplinary origins and contextual dimensions. Environmental Hazards, 7, 383-398.
Shafieezadeh, A., Burden, L.I. (2014): Scenario-Based Resilience Assessment Framework for Critical Infrastructure Systems: Case Study for Seismic Resilience of Seaports. Reliability Engineering \& System Safety, 132, 207-219.

Uday, P., Marais, K. (2015): Designing Resilient Systems-ofSystems: A Survey of Metrics, Methods, and Challenges. The journal of international council on electrical engineering, 18, 491-510.

Urruty, N., Tailliez-Lefebvre, D., Huyghe, Ch. (2016): Stability, robustness, vulnerability and resilience of agricultural systems. A review. Agronomy for Sustainable Development, 36, 1-15.

Wang, D., Ip, W. H. (2009): Evaluation and Analysis of Logistic Network Resilience with Application to Aircraft Servicing. IEEE Systems Journal, 3, 2, 166-173.

Yodo, N., Wang, P. (2016): Engineering Resilience Quantification and System Design Implications: A Literature Survey. Journal of Mechanical Design, 138, 11.

Zobel, C.W., Khansa, L. (2014): Characterizing Multi-Event Disaster Resilience. Computers \& Operations Research, 42, 83-94.

\section{SAŽETAK}

\section{Mjerenje otpornosti strojeva za širokočelno iskapanje}

U radu je opisana primjena koncepta otpornosti u rudarstvu, tj. u radu strojeva koji se rabe kod iskapanja i proizvodnje. Uporabljena je linearna funkcija kao kvantitativna analitička metoda. Pretpostavljeno je kako performanse rudarske opreme padaju na nulu odmah nakon događaja koji označava kvar. Slijedom toga izračun otpornosti postupak je koji u obzir uzima vrijeme potrebno za popravak strojeva u prvobitno radno stanje. Studija slučaja načinjena je s podatcima o kvarovima utvrđenim na sjekačima korištenim u iranskome rudniku (s uzdužnim iskapanjem) Parvadeh i obuhvaćaju dvogodišnje razdoblje vađenja ugljena. Kroz to vrijeme obrađeni su podatci za više od 2600 radnih sati te 171,8 sati utrošenih na popravke. Obradom je izračunano kako otpornost promatranih sjekača iznosi 96,7 \%. Potvrđeno je kako takva otpornost može biti primijenjena kod rudarenja ugljena kao dodatna varijabla kojom se opisuje stabilnost i pouzdanost vađenja rude.

\section{Ključne riječi:}

ugljen, sjekačica, vrijeme popravka, funkcija uspješnosti

\section{Authors' contribution}

Sasan Heydari (PhD candidate and researcher in Mining Machinery Lab) completed the literature review and provided field studies, data collection, data refining, and statistical analysis. Seyed Hadi Hoseinie (Assistant Prof. and Head of Mining Machinery Lab) designed the research flow and field data collection process along with article preparation. Behzad Ghodrati (Professor) and Uday Kumar (Chair Professor) had a deep contribution to the development of the concept and scope of the resilience. They provided broad discussions to get the most accurate assumptions and analytical analysis. 